\title{
Aplikasi Absen Kuliah Menggunakan Kode QR (Quick Response)
}

\author{
Riski Tuloli ${ }^{1 *}$ ) \\ Program Studi Teknik Informatika, Politeknik Gorontalo \\ email: riski.mhs15@ti.poligon.ac.id
}

\begin{abstract}
Selama ini sistem absensi mahasiswa di Politeknik Gorontalo masih menggunakan evaluasi secara manual dengan cara setiap mahasiswa membubuhkan tanda tangannya di lembar absensi mata kuliah. Hal ini banyak menimbulkan kendala diantaranya sering terjadi kesalahan jumlah kehadiran mahasiswa dalam setiap pertemuan selain itu juga untuk rekapan absensi dari setiap mata kuliah tidak pernah dibuat. Untuk mengatasi persoalan tersebut, maka dirancang sebuah aplikasi absensi mahasiswa menggunakan Kode QR berbasis android di Politeknik Gorontalo. Perbedaan pada penelitian ini terletak pada metode yang digunakan yaitu Kode QR merupakan evaluasi kode batang dari satu dimensi menjadi dua dimensi. Diharapkan dengan dibuatkan aplikasi absen kuliah dengan menggunakan Kode QR di Politeknik Gorontalo permasalahan yang sering terjadi bisa teratasi, sehingga dosen dan mahasiswa bisa melihat sendiri jumlah kehadiran dari setiap mahasiswa. Untuk mengatasi masalah tersebut, dirancang sebuah Aplikasi absensi mahasiswa menggunakan kode QR berbasis android di Politeknik Gorontalo. Dengan aplikasi ini dosen dapat melakukan absensi mahasiswa melalui kode QR yang tertera pada kartu mahasiswa menggunakan smartphone android sebagai pembaca kode QR, sehingga dosen tidak perlu lagi mencatat absensi mahasiswa. Berdasarkan hasil simulasi yang dilakukan Aplikasi Kode QR bias berjalan dengan baik dan bias di gunakan pada Sistem Informasi Akademik.
\end{abstract}

Kata Kunci: Android, absensi, smartphone, Kode QR

\section{PENDAHULUAN}

Android adalah sebuah kumpulan perangkat lunak untuk mobile. Android menyediakan platform terbuka bagi para developer untuk menciptakan aplikasi mereka sendiri. Adapun bahasa pemograman yang terdapat pada android adalah bahasa pemograman java. [1]

Melalui hasil observasi dari masing-masing Program Studi yang ada di Politeknik Gorontalo, selama ini sistem absensi mahasiswa yang sudah berjalan selama 8 tahun masih menggunakan evaluasi secara manual. Dengan cara setiap mahasiswa dalam setiap pertemuan mahasiswa
Ismail Mohidin ${ }^{2)}$

Program Studi Teknik Informatika, Politeknik Gorontalo

email: is.mohidin@poligon.ac.id

membubuhkan tanda-tangannya pada lembar absensi mata kuliah, di mana sering terjadi kesalahan jumlah kehadiran mahasiswa dalam setiap pertemuan. Selain itu juga rekapan absensi dari setiap mata kuliah belum pernah dibuat.

Dari permasalahan tersebut, maka penulis mencoba untuk membuat Aplikasi Absensi Kuliah Dengan Menggunakan kode QR berbasis mobile di Politeknik Gorontalo. Dengan aplikasi ini dosen dapat melakukan absensi pada mahasiswa dengan cara melakukan scan kartu absen mahasiswa, dengan begitu mahasiswa juga tidak perlu lagi membubuhkan tanda-tangannya pada setiap kehadiran dimata kuliah.

Diharapkan dengan adanya aplikasi absensi kuliah dengan menggunakan Kode QR dosen tidak perlu lagi membawa absen mahasiswa di setiap perkuliahan. Begitu juga dengan mahasiswa tidak perlu lagi membubuhkan tanda-tangannya pada setiap pertemuan, cukup dengan membawa kartu absensi. Aplikasi ini juga memberikan rekapan absensi mahasiswa dari setiap mata kuliah sehingga para dosen bisa memonitor tingkat kehadiran dari setiap mahasiswa. Beberapa hal inilah yang mendorong pemikiran mengenai membangun sistem yang dapat melakukan absensi mahasiswa secara mobile, cepat, efektif dan efisien. Android dan Kode QR digunakan dalam penelitian ini karena android merupakan OS (Operating System) mobile yang sangat populer dan banyak digunakan dan Kode QR merupakan media yang digunakan dalam penyampaian informasi secara cepat dan mendapat respons yang cepat tanpa melakukan input secara manual dengan cara menginput data. Informasi yang dikodekan dalam Kode QR dapat berupa URL, nomor telpon,pesan SMS, V-Card atau teks apapun.

\section{PEMBAHASAN}

Gambaran rancangan aplikasi yang akan diterapkan di Politeknik Gorontalo mengggunakan Kode QR.

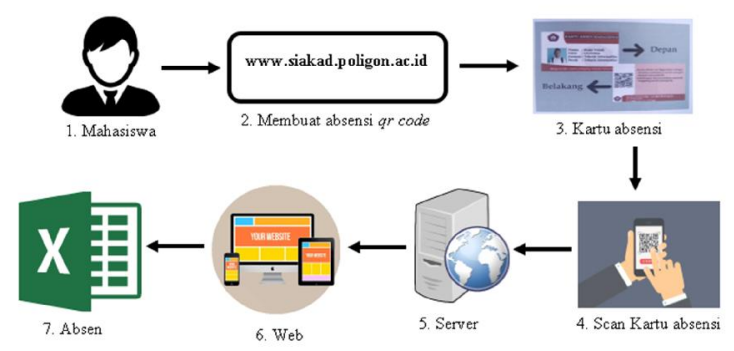

Gambar 1. Gambaran Sistem 
2.2. Data Inputan

Data yang di olah dalam proses ini adalah data mahasiswa yang sudah valid dari semua program studi yaitu Program studi TI, THP dan MPP sebanyak 30 data Mahasiswa. Kemudian untuk data dosen dan mata kuliah diambil dari 3 program studi yang ada di Politeknik Gorontalo.

\subsection{Kartu Absen Kode QR}

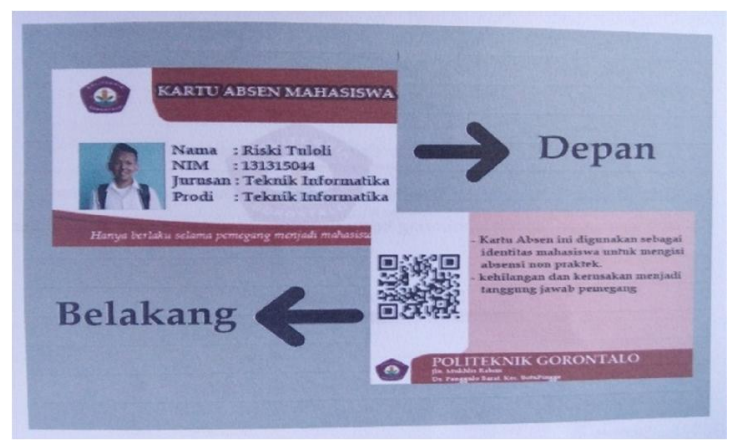

Gambar 3. Kartu Absen Kode QR

Kartu Kode QR ini digunakan sebagai data inputan. Untuk data mahasiswa sendiri akan dibuatkan kartu Kode QR yang sudah di generate dalam sistem informasi akademik (SIAKAD) Politeknik Gorontalo.

\subsection{Pengolah Data}

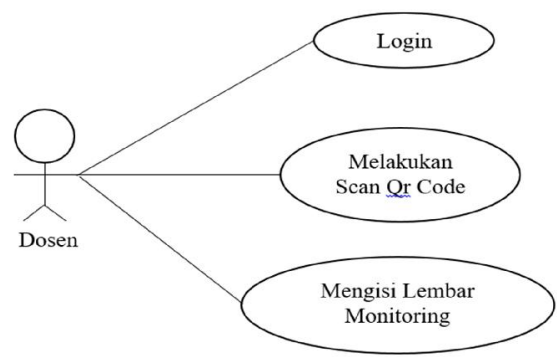

Gambar 4. Use Case Pada Aplikasi

Pada Gambar 4 diatas dosen akan Melakukan scan pada kartu absen mahaiswa kemudian mengisi lembar monitoring kemudian akan di submit. Data tersebut akan terkirim ke server.

Gambar 5 gram absensi mahasiswa Politeknik Gorontalo dilakukan oleh dosen.

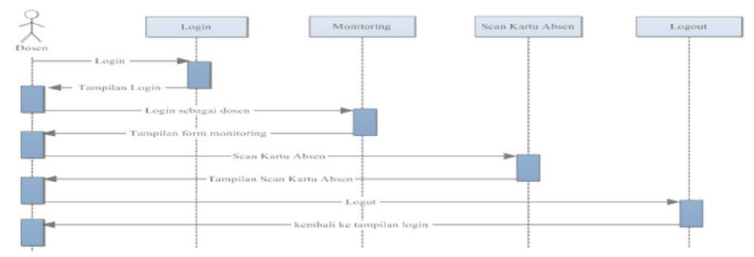

Gambar 5. Seauence diagram aktor dosen

\section{Aplikasi Absen Kuliah Menggunakan Kode QR (Quick Response)}


2.6. Rancangan Database

Aplikasi Absensi Kuliah Menggunakan Kode QR di Politeknik Gorontalo ini menggunakan database MySQL. MySQL adalah sistem manajemen database $S Q L$ yang bersifat Open Source dan paling populer saat ini. Sistem Database MySQL mendukung beberapa fitur seperti multithreaded, multi-user, dan $S Q L$ database managemen sistem (DBMS). Database ini dibuat untuk keperluan sistem database yang cepat, handal dan mudah digunakan.

Adapun rancangan database dari Aplikasi Absensi Kuliah Menggunakan Kode QR di Politeknik Gorontalo adalah sebagai berikut:

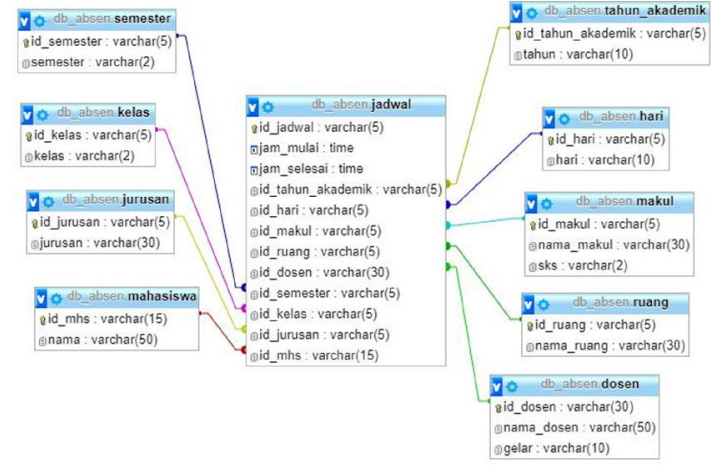

Gambar 7. Rancangan database

Rancangan database di Gambar 8 dibuat dalam bentuk CDM atau Conceptual Data Model, dimana database tersebut memiliki 14 tabel, diantaranya :

Gambar 6. Class diagram

Gambar 6 adalah class diagram menggambarkan struktur class apa yang terlibat didalam aplikasi absen kuliah menggunakan Kode QR di Politeknik Gorontalo.

\subsection{Entity Relation Diagram}

Entity Relationship Diagram (ERD) adalah susunan data yang disimpan dalam sistem secara abstrck. ERD merupakan data yang menekankan pada strukturstruktur dan relationship data.

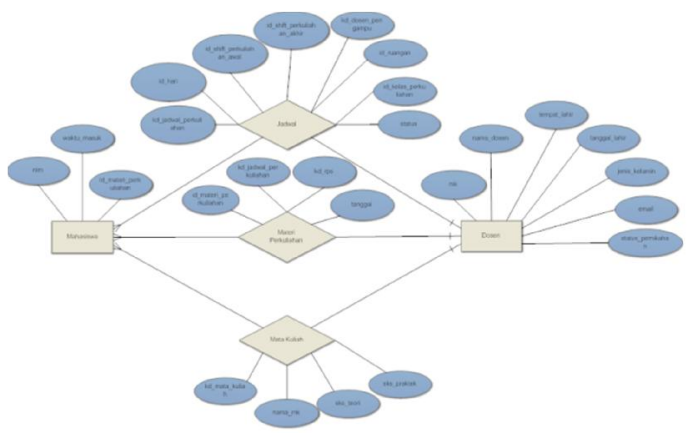

Gambar 6. Entity Relation Diagram

1. Tabel Mahasiswa

Untuk menampung id_mhs dan nama mahasiswa. Dengan primary key id_mhs. Dimana tabel ini berelasi dengan tabel absen.

2. Tabel Dosen

Untuk menampung id_dosen, nama_dosen dan gelar. Dengan primary key id dosen. Dimana tabel ini berelasi dengan tabel jadwal.

3. Tabel Semester

Untuk menampung id_semester dan semester. Dengan primary key id_semester. Dimana tabel ini berelasi dengan tabel jadwal.

4. Tabel Kelas

Untuk menampung id_kelas dan kelas. Dengan primary key id kelas. Dimana tabel ini berelasi dengan tabel jadwal.

5. Tabel Jurusan

Untuk menampung id jurusan dan jurusan. Dengan primary key id jurusan. Dimana tabel ini berelasi dengan tabel jadwal.

6. Tabel Tahun Akademik

Untuk menampung id tahun_akademik dan tahun. Dengan primary key id_tahun_akademik. Dimana tabel ini berelasi dengan tabel jadwal.

7. Tabel Hari

ISSN : 2502-1613 
Untuk menampung id_hari dan hari. Dengan primary key id_hari. Dimana tabel ini berelasi dengan tabel jadwal.

8. Tabel Ruang

Untuk menampung id_ruang dan_ruang. Dengan primary key id kelas. Dimana tabel ini berelasi dengan tabel jadwal.

9. Tabel Mata Kuliah

Untuk menampung id_makul, nama_makul dan sks. Dengan primary key id_makul. Dimana tabel ini berelasi dengan tabel jadwal.

10. Tabel Jadwal

Untuk menampung. Dengan primary key id_jadwal. Dimana tabel ini berelasi dengan tabel mahasiswa, dosen, makul, semester, Tahun_akademik, ruang,hari dan jurusan.

11. Tabel Monitor

Untuk menampung id_monitor, id_pertemuan, nama_dosen, materi dan kehadiran_mhs. Dengan primary key id monitor. Dimana tabel ini berelasi dengan tabel absen dan tabel pertemuan.

12. Tabel waktu

Untuk menampung id waktu, jam mulai dan jam_selesai. Dengan primary key id_waktu. Dimana tabel ini berelasi dengan tabel jadwal.

13. Tabel Absen

Untuk menampung status Dengan primary key Id_absen. Dimana tabel ini berelasi dengan tabel mahasiswa,monitoring dan jadwal.

14. Tabel pertemuan

Untuk menampung id_pertemuan dan pertemuan Dengan primary key id pertemuan. Dimana tabel ini berelasi dengan tabel monitoring

\subsection{Alur Pada Aplikasi}

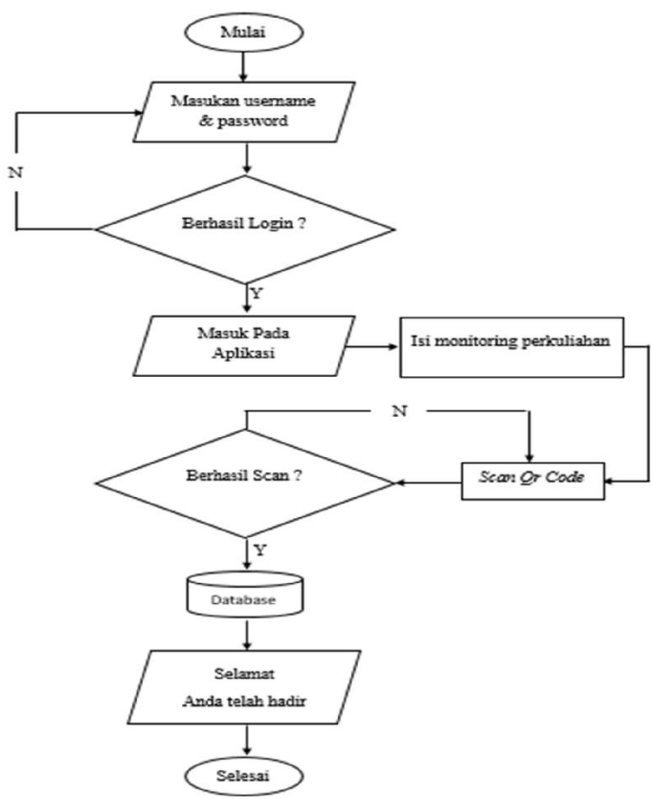

Gambar 8. Alur flowchart pada aplikasi
Deskripsi dari Gambar 9 adalah sebagai berikut :

1. Login yang digunakan adalah akun yang sudah didaftarkan melalui sistem informasi akademik Politeknik Gorontalo

2. Dosen mengisi form monitoring tentang materi yang akan diberikan pada saat mengajar

3. Kemudian setelah dosen selesai mengisi monitoring, selanjutnya langsung melakukan proses absensi pada mahasiswa dengan cara mengscan karu absensi mahasiswa.

4. Setelah proses absensi selesai maka hasil tersebut akan tersimpan di penyimpanan yang sudah di sediakan seperti database.

Setelah berhasil tersimpan di peyimpanan dengan begitu mahasiswa sudah terhitung hadir pada matakuliah yang diikuti.

2.6. Tampilan Layout Aplikasi

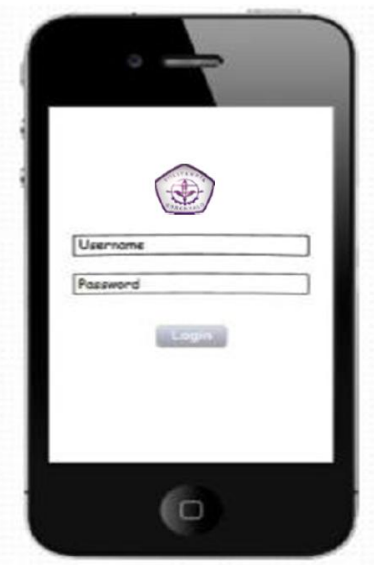

Gambar 9. Tampilan login

Pada Gambar 10 login yang di gunakan dalam proses ini adalah akun yang sudah di daftarkan melalui sistem informasi SIAKAD Politeknik Gorontalo. Sehingga akun yang digunakan adalah akun yang sudah di verifikasi oleh admin pengelolah SIAKAD. Setelah berhasil login maka akan masuk kehalaman berikutnya.

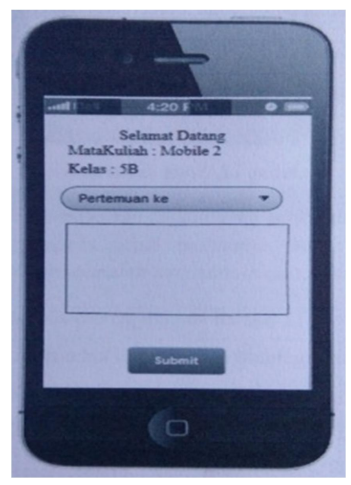

Gambar 10. Tampilan mengisi form

\section{Aplikasi Absen Kuliah Menggunakan Kode QR (Quick Response)}




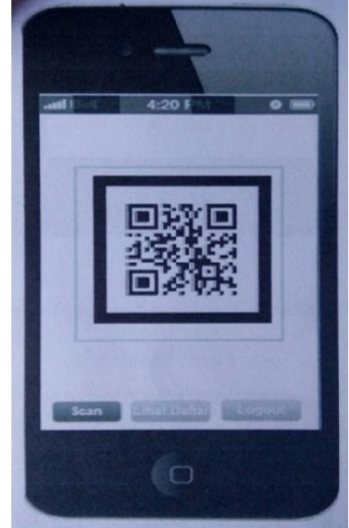

Gambar 11. Tampilan scan Kode QR

Pada Gambar 11 ditampilan halaman menu dari proses monitoring perkuliahan, disini sistem sudah mengenali mata kuliah dan kelas yang akan di ajarkan oleh dosen. Kemudian mengisi monitoring perkuliahan untuk mengetahui pertemuan capaian materi yang diajarkan oleh setiap dosen. Setelah itu data di submit ke server.

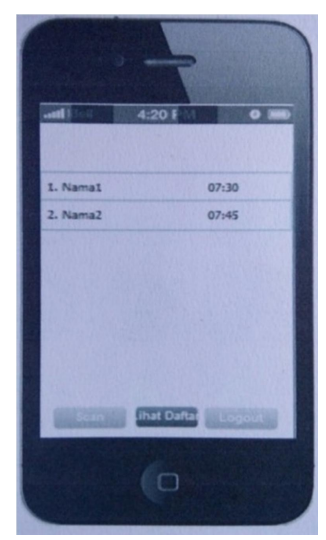

Gambar 12. Halaman daftar absensi

Pada Gambar 12 Scan Kode QR di gunakan untuk memverifikasi setiap akun mahasiswa yang sudah dibuatkan kartu absensi mahasiswa, sehingga dosen akan mengetahui hadir tidaknya setiap mahasiswa dalam perkuliahan.

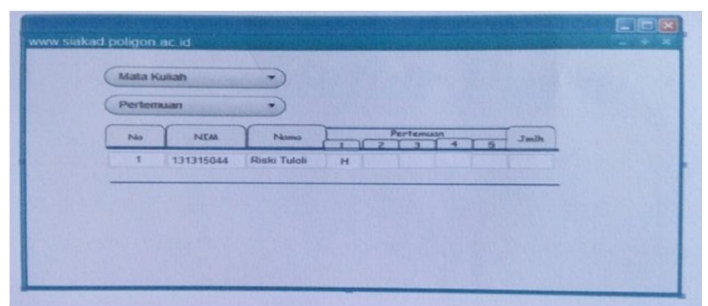

Gambar 13. Hasil rekapan absensi pada sisi web
Kemudian pada Gambar 13 adalah setelah proses absensi berhasil, maka dosen yang bersangkutan akan mengetahui setiap detail kehadiran mahasiswa dan akan di submit ke SIAKAD, sehingga datanya bisa ditampilkan secara statistik. Dan akan menampikan data absensi mahasiswa yang sudah mengisi daftar hadir dengan cara dosen sudah melakukan scan kartu absen mahasiswa dengan smartphone.

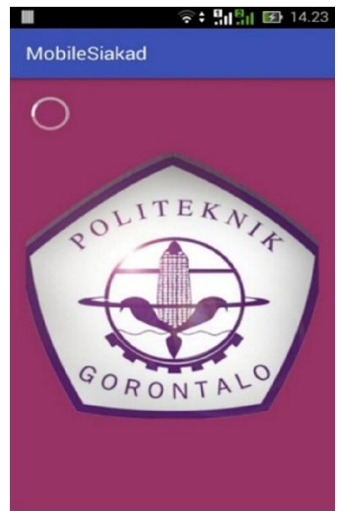

Gambar 14. Splash

Pada gambar 14 adalah tampilan hasil rekapan absensi mahasiswa yang sudah mengisi daftar hadir dengan cara dosen sudah melakukan scan kartu absen mahasiswa, kemudian hasil scan tersebut akan muncul pada webnya yaitu nama mahasiswa, nim, mata kuliah yang diikuti kemudian mahasiswa tersebut berstatuskan hadir.

\section{IMPLEMENTASI}

Implementasi adalah suatu proses untuk menempatkan dan menerapkan informasi dalam aplikasi. Setelah aplikasi dianalisis maka akan menuju tahap implementasi. Dalam implementasi Aplikasi Absen Kuliah Dengan Menggunakan Kode QR Di Politeknik Gorontalo ini dapat dijalankan pada perangkat smartphone dengan platform Android minimal versi Froyo (2.2).

3.1. Halaman Splash Aplikasi

Splash Screen adalah suatu kondisi yang digunakan untuk menggambarkan image atau gambar yang muncul pada saat sebuah aplikasi atau program dalam proses loading.

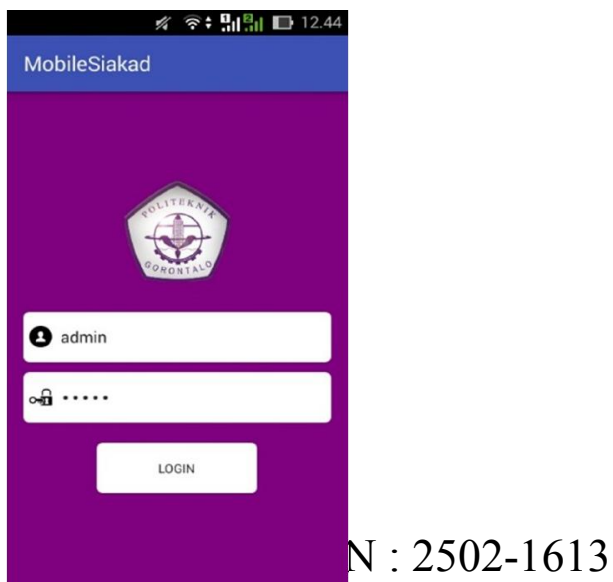

Gambar 15. Tampilan login pada mobile 
kartu absensi yang sudah tertera Kode QR sebagai identitas diri mahasiswa itu sendiri, menu list adalah daftar mahasiswa yang hadir.

Pada Gambar 16 adalah untuk tampilan awal aplikasi, yaitu halaman dimana semua user atau pengguna melakukan proses login dengan cara memasukkan username dan password untuk dapat memulai aplikasi dan masuk ketampilan selanjutnya. Dimana proses login ini untuk mengverifikasi username dan password yang valid adalah syarat untuk masuk ke aplikasi.

\subsection{Halaman Monitoring}

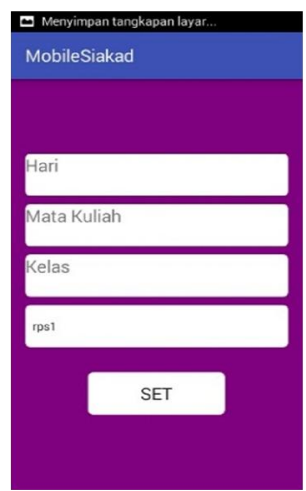

Gambar 16. Tampilan halaman monitoring

Pada halaman monitoring adalah untuk dimana pada halaman ini dosen mengisi materi perkuliahan sesuai dengan RPS yang sudah ada. Yang sudah terisi otomatis hari, mata kuliah, dan dosen pengampu

\subsection{Halaman Home Aplikasi}

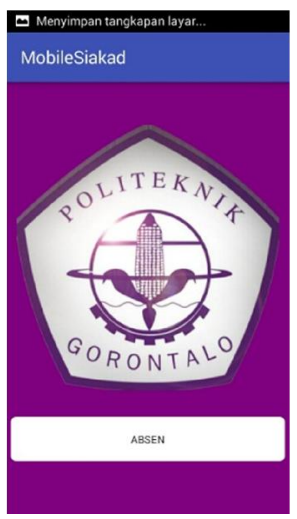

Gambar 17. Tampilan halaman scan kartu absen

Pada Gambar 18 adalah untuk halaman home aplikasi dimana pada halaman ini dosen dapat memilih menu-menu yang sudah tersedia pada halaman tersebut. Pada menu scan dosen akan mengabsen mahasiswa dengan cara mengscan

\subsection{Halaman Scan Kartu Absensi}

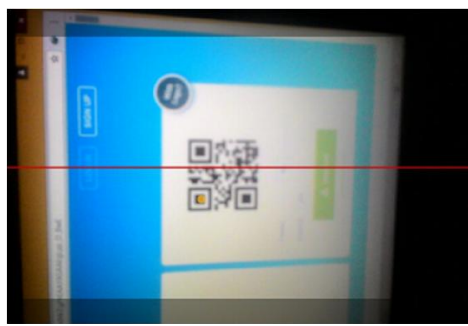

Gambar 18. Tampilan proses scan kartu absen

Pada Gambar 19 adalah menjelaskan proses scan Kode QR dari smartphone, jika data yang di proses ada dalam sistem maka data tersebut akan di kirim ke server dan di proses disisi web SIAKAD Politeknik Gorontalo yang akan menjadi informasi pada civitas academica Politeknik Gorontalo.

\subsection{Halaman Login Pada sisi $W E B$ SIAKAD}

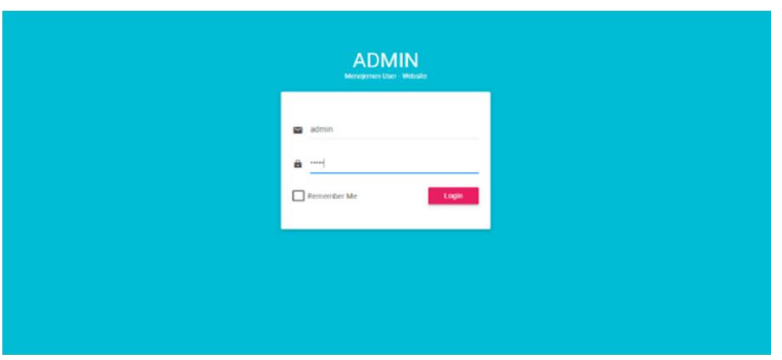

Gambar 19. Tampilan halaman login pada sisi web

Pada Gambar 20 adalah halaman login sistem pada sisi $W E B$, yaitu halaman dimana semua pengguna melakukan proses login dengan memasukkan username dan password untuk dapat menggunakan Sistem Informasi Akademik Politeknik Gorontalo.

\subsection{Halaman Absen Pada Sisi WEB SIAKAD}

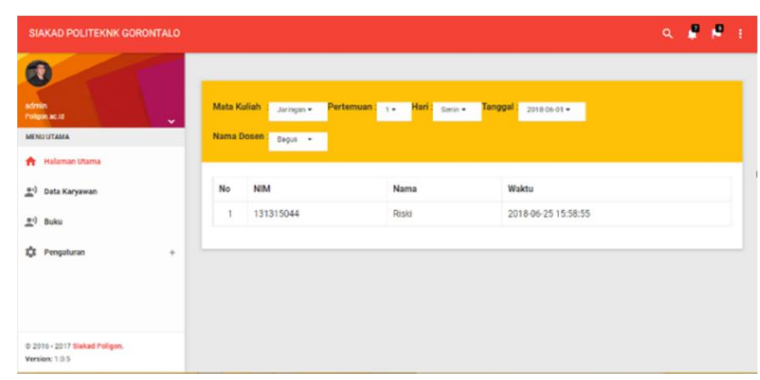

Gambar 20. Tampilan halaman daftar absen mahasiswa

Pada Gambar 21 adalah halaman daftar mahasiswa yang sudah terabsen dari sisi smartphone. Dimana pada halaman

\section{Aplikasi Absen Kuliah Menggunakan Kode QR (Quick Response)}


JTII. VOL. 3. NO. 2. NOPEMBER $2018: 61-67$

ini dosen bersangkutan dapat melihat daftar mahasiswa yang smengikuti mata kuliah.

\section{KESIMPULAN}

Dengan adanya aplikasi ini maka setiap mahasiswa Politeknik Gorontalo tidak perlu lagi bersusah payah untuk mengisi absen dengan menanda tangani absen dari Program Studi. Mahasiswa juga dapat melihat transparansi kehadiran dari setiap mahasiswa di setiap mata kuliah. Dengan demikian mahasiswa dapat mengetahui kinerja dosen yang ada di Politeknik Gorontalo.

\section{SARAN}

Aplikasi ini masih dapat dikembangkan lagi, dengan cara mengabsen mahasiswa dengan cara memakai kamera cctv untuk menagkap face dari mahasiswa dalam suatu ruangan.

\section{DAFTAR PUSTAKA}

[1] E. Rahmat et al., "Menggunakan Kode QR reader berbasis android ( studi kasus: fakultas ilmu komputer jurusan sistem informasi unsri )," .

[2] I. Novian, H. Rahcaya, "( Kode QR ) berbasis android di smk shifa."

[3] B. S. Eko and K. Bobi, "Perancangan sistem absensi kehadiran perkuliahan dengan menggunakan radio frequency identification ( RFId ),"

[4] D. L. Tresnani and K. Kunci, "Menggunakan Kode QR pada smartphone,"

[5] A. R. Safitri, L. A. Sholikhan, "Pengguna Kode QR dalam presensi berbasis android".

[6] A. Absensi, s. Di, s. M. K. Muhammadiyah, s. Berbasis, and b. Dan, "Aplikasi absensi siswa di smk muhammadiyah 1 sukoharjo berbasis barcode dan sms," 2009.

[7] M. Malik, H. Kariim, J. Teknologi, and S. Semarang, "Pengembangan sistem absensi karyawan dengan fungsi pengambilan cuti di pt nayati indonesia berbasis client server muhammad malik hakiim kariim jurusan teknologi informasi dan komputer, stekom semarang,"

[8] P. W. Sari, “ Pengolahan data presensi guru dan karyawan smp gunungjati 2 purwokerto berbasis barcode". 